INTERNATIONAL JOURNAL OF

MULTIDISCIPLINARY STUDIES IN ARCHITECTURE

AND CULTURAL HERITAGE

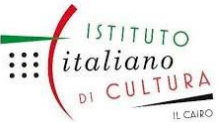

\title{
Documentation History in the Egyptian Museum Cairo and Its Impact on Collections Management
}

Mahrous Elsanadidy a, $b$, *

a Ph.D. Candidate in the Heritage and Museum Studies, Helwan University.

b Chief Curator in the National Museum of Egyptian Civilization.

\begin{tabular}{l} 
Abstract \\
Egyptian Museum Cairo is considered one of the largest museums all over the world, containing ancient Egyptian antiquities \\
telling the history of ancient Egyptians' lives; more one hundred sixty thousand objects are on display and the thousands else are \\
in the basement and upper floor magazines. Those objects are representing different ancient periods from the lithic periods to \\
Greco-Roman via Pharaonic periods. \\
\hline Keywords \\
- Documentation. \\
History. \\
Egyptian Museum. \\
- Collections Management. \\
Heritage.
\end{tabular}

Introduction

The Egyptian Museum Cairo is one of the oldest museums among Egypt's museums. The first idea for its establishment dates back to the reign of Muhammad Ali Pasha (1805-1849A.D) ${ }^{1}$. when he had issued a decree to prohibit the illicit digging and trafficking of antiquities which increased in a horrible way, in particularly, after a French military campaign to Egypt (1798-1801), and also as to the results of what was written by the scientists of Napoleon Bonaparte ${ }^{2}$ about Egypt including its monuments ${ }^{3}$ and solving the decipherment of ancient

\footnotetext{
${ }^{1}$ Muhammad Ali was Egypt 's governor under Ottoman Empire between 1805 and 1849 A.D.

2 Napoléon Bonaparte $(1769-1821)$ was a French military and political leader who rose to prominence during the French revolution and led several campaigns including one campaign to Egypt in 1798 .

${ }^{3}$ The French scientists accompanied Napoleon Bonaparte wrote series of volumes during a French campaign to Egypt (1798 - 1801) called "Description de l'Égypte " describe, and illustrate Egypt; geographical, environmental,naturally, archaeological, economical commercial.
} 
INTERNATIONAL JOURNAL OF

MULTIDISCIPLINARY STUDIES IN ARCHITECTURE

AND CULTURAL HERITAGE

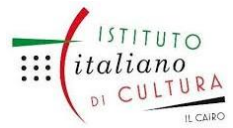

Egyptian language by Jean-Francois Champollion ${ }^{4}$ in 1822 . Hence, the ancient Egyptian monuments became popular goods in the European markets. Therefore, European consuls to Egypt like Salt, Drovetti, Anastasi and travellers activated to collect ancient Egyptian antiquities which are now forming principal collections of European museums ${ }^{5}$. This decree contained three articles as follows; Article1 describes "what is an antiquity thing?", Article 2, is for collecting old things in a certain place (Ezbekiyya museum), and Article 3 is prohibitingthe export of antiquity things to outside Egypt ${ }^{6}$. Then Mr. Linnant Bey was entrusted by Youssef Zia Effendi, the first antiquities service director under a supervision of Elshiekh RefahEltahtawy ${ }^{7}$, to inventory the ancient sites and objects and to bring objects to a museum ${ }^{8}$. Then a large number of objects were collected at the civilian school existed in an old palace near from the Ezbekiyya Lake ${ }^{9}$. But unfortunately, these collections were gradually gifted by EgyptGovernors as diplomatic ways with European elite Visitors. So a number of this collection began to reduce and it was finally moved to a hall in the ministry of public instruction at Salaheldin Citadel. In 1854, Abbas Pasha ${ }^{10}$ put an end to the existence of the first Egyptian museum of Cairo, when he gifted remains of its collection to the Austria Archduke Maximilianwho was visiting Egypt ${ }^{11}$

In 1858, Auguste Marriette convinced the Egypt Viceroy Said Pasha (18541863) to build a new museum at Beaulaq on the eastern bank of the River Nile, which it was actually opened in $1863^{12}$ at the reign of Khedive Ismael (1863-1879). But, unfortunately again, it wasdestroyed by a high flood in 1878 which caused a big damage and loss of most objects.

\footnotetext{
${ }^{4}$ Jean-Francois Champollion, French Egyptologist, is a god father of Egyptology who solved the decipherment ofancient Egyptian Language in 1822.
} 


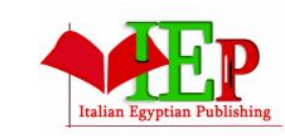

ISSN: $2735-4415$
INTERNATIONAL JOURNAL OF

\section{MULTIDISCIPLINARY STUDIES IN ARCHITECTURE}

AND CULTURAL HERITAGE

VOLUME 2, ISSUE 2, 2019, $85-96$.

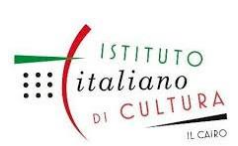

www.egyptfuture.org/ojs/

${ }^{5}$ Corteggiani, Jean-Pierre; I'Egypte des pharaons au musèe du caire. Paris, 1979.7- 9.

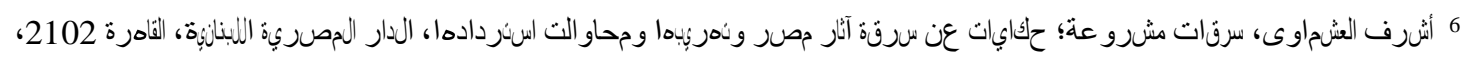

ص. 01 -06

${ }^{7}$ Elshiekh Refah Eltahtawy is one of a pioneer generation who travelled to France, and transferred the modernEuropean sciences to Egypt and a leader of education renaissance at the time of Muhammad Ali Pasha to Ismael.

${ }^{8}$ Corteggiani, Jean-Pierre; op.cit. 10.

${ }^{9}$ ibid.10.

${ }^{10}$ Abbas Pasha was Mohammed Ali's successor and Egypt governor under Ottoman Empire between 1849- 1854A.D.

${ }^{11}$ Saleh, Mohamed and Sourouzian, Hourig; The Egyptian museum Cairo; Official catalogue, the organization ofEgyptian Antiquities, Cairo 1987. 9.

12 Morlier, Helene; " Avant le concours: les muse de Beaulaq et de Giza, De la conservation du materiel archeologique a l' exposition pour le public"; in Concours pour le musee des antiquties Egyptiennes du caire, 1895, p.14-21-22.

Afterthat, the rest of its contents were moved to a Giza palace ${ }^{13}$ till the current building of Egyptian Museum at Tahrir square (former Ismaelia square) was inaugurated in $1902^{14}$.

Now, Egyptian Museum Cairo is considered one of the largest museums all over the world, containing ancient Egyptian antiquities telling the history of ancient Egyptians' lives; more one hundred sixty thousand objects are on display and the thousands else are in the basement and upper floor magazines. Those objects are representing different ancient periods from the lithic periods to Greco-Roman via Pharaonic periods. As for, The sections of Egyptian Museum Cairo can be identified as follows; Section 1: Jewelry, Tutankhamun, and Royal Mummies, Section 2: Prehistoric Periods through Old Kingdom, Section 3: Middle Kingdom, Section 4: New Kingdom, Section 5: Third Intermediate Periods through Greco- Roman, 
INTERNATIONAL JOURNAL OF

MULTIDISCIPLINARY STUDIES IN ARCHITECTURE

AND CULTURAL HERITAGE

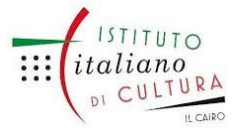

ISSN: $2735-4415$

VOLUME 2, ISSUE 2, 2019, 85 - 96.

www.egyptfuture.org/ojs/

Section 6-C: Coins, Section 6-P: Papyri, Section 7: Ostraca, Coffins, and Scarabs, Recently a new "section" was added to these sections called Section 8: Basement ${ }^{15}$.

\section{Documentation history of the Egyptian Museum Cairo:}

The actual history for scientific documentation in Egyptian Museum Cairo dates back when Auguste Mariette was appointed as a director of Egyptian Antiquities service and Egyptian museum in1858. In the following year, he started to build a museum at Beaulaq quarter on the River Nile, and he set procedural steps for recording the collected objects from the discoveries through archaeological sites Egypt wide. So, as soon as possible the object arrives to a museum, it should be recorded in a register book called "Journal d'entrée". the Journal d' entrėe" (JE) is a main inventory register book which its pages are divided to columns with metadata about; Accession number (ID No), Position, Description, Material, Date, Dimensions, Provenance, Finder, Excavation number, Registration date, Remarks, and Illustration or Image which was added later when a camera became available ${ }^{16}($ fig.1). Then, itwas followed by publishing the first Catalogue General called Album du Musèe de Boulaq in

\footnotetext{
${ }^{13}$ A brief description of prinipal monuments. (1988). Cairo: General Egyptian book organization.p.11.

${ }^{14}$ El-Saddik, Wafaa; "The Egyptian Museum". Heritage Landscape of Egypt. Paris:UNESCO, 2005.31-

2; Corteggiani, Jean-Pierre; I'Egypte des pharaons au musée du caire. Paris, 1979.5-6.

${ }^{15}$ The Registration Collections Management and Documentation Department; Protocol Book, 2010. 58.

${ }^{16}$ Bothmer, Bernard .V; "Numbering Systems of the Cairo Museum". Textes et Langages de L' Égypte Pharaonique; Cent Cinquante Années de Recherches1822- 1972, Hommage à Jean François Champollion. Le Caire: IFAO, 1972 . 112-3.
} 
$1872^{17}$. When the current building was inaugurated in 1902, Gustin Maspero, Museum director, and his assistants started to publish a museum guide book and series of Catalogue General (CG) (fig.2). Later, to give objects more securing, and to ease its accountability and inventory, another register books were added for each section entitled "Special register books(SR)". and if the objects | objet will stay for short loan shound be recorded in another register book entitled "temporary register books (TR)"18.

In 2000, it was the first trial for a digital documentation Project in Cooperation with the Ministry of Communications, but it failed because of lack of funding.

In 2006, a digital documentation project called " Egyptian Museum Database Project" funded by the United States of Agency for International Development (USAID) and the American Research Center in Egypt (ARCE), using KE EMu system (fig.4) has started to record the displaying objects with creating a digital photos archive ${ }^{19}$. At the present, a numberof objects recorded arrived for more 160.000 objects.

\section{Registration steps in Egyptian Museum Cairo}

The Egyptian Ministry of Antiquities through its laws, regulations and decrees listed several steps to register and document object through museums, as follows:

\section{Step 1:}

A decree by the Minster of Antiquities or the Secretary General of the Supreme council 
INTERNATIONAL JOURNAL OF

MULTIDISCIPLINARY STUDIES IN ARCHITECTURE

AND CULTURAL HERITAGE

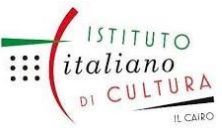

of Antiquities is issued for moving certain object or objects from its sites, magazines or museums to a certain museum. This decree is based on laws and regulations related to laws ofAntiquities protection, an approval of a permanent committee, suggestions or recommendations of the sites, magazines, and museums managers, or Committees assigned tochoose objects for a certain museum. a decree includes the procedural steps, roles, time tables,members, and how it will be carried out as well 20 .

\footnotetext{
${ }^{17}$ Marriete, Auguste, Delle, M.M., et Bechard; Album du musėe de Boulaq; avec un texte explicatif, le Caire 1872.

${ }^{18}$ The Registration Collections Management and Documentation Department; Protocol Book, 2010. 56.

${ }^{19}$ Ibid.17.
}

\section{Steps 2:}

Joint committee of two parts (sender and receiver) is formed of at least three archaeologists to record the object. . In the case of the objects/ object will be stay as permanentacquisition, it has to record in the Journal d'entrèe (JE) with the same data as aforementioned,and they/ it take/s a new accession number following to the last former number with writing itby black ink, then they/ it are/ is distributed to a special section according to its classificationas aforementioned, where they/it take/s a new special number in a Special Register book (SR)following to the last former number with writing it by white ink ${ }^{21}$.

If objects/ object will stay for a short loan in, they/ it will be recorded in a temporary register book (TR) with giving a new temporary accession number written in crossing form contains the receiving date and the last number of that day as follows; day/ month/ year/ the last number of that day (20/10/16/ 1) with the 
INTERNATIONAL JOURNAL OF

MULTIDISCIPLINARY STUDIES IN ARCHITECTURE

AND CULTURAL HERITAGE

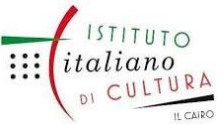

same data of the former owner, and some new information added such as; new position, registration date, former numbers, remarks and imageor illustration (fig.3).

\section{Catalogues:}

Egyptian Museum has series of catalogue general classified in accordance to themes orcollections such as; the royal mummies ${ }^{22}$, Statues et Statuette des Rois et de Particuliers ${ }^{23}$, Canopics ${ }^{24}$, Models of ships and boats ${ }^{25}$, Anthropoid clay coffins $^{26}$. In regarding to the Data mentioned in catalogues; Catalogue number, Object title, Dimensions, Full description, Techniques, if inscriptions, Condition of object, Illustrations. As for, writing a catalogue

\footnotetext{
${ }^{21}$ Saleh, Mohamed and Sourouzian, Hourig; The Egyptian museum Cairo; Official catalogue.the organization ofthe Egyptian Antiquities, Cairo 1987.12.

${ }^{22}$ Smith, Elliot. G; Catalogue General of Egyptian Antiquities in the Cairo Museum; the royal mummies, Cairo1912.

${ }^{23}$ Legrain, George. Catalogue General of Egyptian Antiquities in the Cairo Museum; statues et statuette des roiset de particuliers. Cairo 1914.

${ }^{24}$ Reisner, Georges. A; Catalogue General of Egyptian Antiquities in the Cairo Museum; Canopics. Cairo 1967.

${ }^{25}$ Reisner, Georges. A; Catalogue General of Egyptian Antiquities in the Cairo Museum; models of ships andboats. Cairo 1913.

${ }^{26}$ Sabbahy, Lisa; Catalogue General of Egyptian Antiquities in the Cairo Museum; Anthropoid clay coffins. AUC
}

general number on the object, is usually written by red ink and sometimes by black or white ink ${ }^{27}$. 
INTERNATIONAL JOURNAL OF

MULTIDISCIPLINARY STUDIES IN ARCHITECTURE

AND CULTURAL HERITAGE

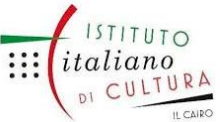

\section{Digital Registration}

After the former step, a Registrar of Digital Registration office is transferring the entiredata recorded in all register books on a prepared format sheet, then he / she inserts them on Database programme. This step is followed with a research phase about all information concerns each object or collection including reports, publications $^{28}$.

\section{Information Categories and groups mentioned on Database system:}

Each record consists of three principal parts: fundamental information about the object including ID numbers, title, dating, provenance, material, dimensions, and acquisition information; images of the object; and the object's permanent location.

Data of digital catalogue records; Title, ID number, Accession information, Sculpture, Physical description, Multimedia, Recorder, Location.

Data of Events; Event title, description, Event date, Dead line, Task, Request, Notes, security.

Data of Loans; Loan number, Loan direction (incoming/ outgoing), Loan status, Loan detail (browser/ lender, role, phone, fax, e-mail), Loan information (short name, title, associated, loansupervision), Date, Task, Finance, Multimedia, Note. 
INTERNATIONAL JOURNAL OF

MULTIDISCIPLINARY STUDIES IN ARCHITECTURE

AND CULTURAL HERITAGE

Data of Movements; Internal movement (object, location, curator in charge, purpose, committee head, registrars, security, date moved, time moved), Note.

${ }^{27}$ Saleh, Mohamed and Sourouzian, Hourig. The Egyptian museum Cairo; Official catalogue, the organization of the Egyptian Antiquities, Cairo 1987.12.

${ }^{28}$ Information adopted from a survey with the curators of registration office of the Egyptian Museum Cairo.

Data of Locations; Identifier (location code, barcode), Location type (location, holder), Location hierarchy, Location supervisor, Holder.

Data of Bibliography; Publication detail (type, language), Book detail (title, abbreviation, author, edition, volume, page, publisher, Publication date, Publication city), Reference (reference type, reference detail), Published in.

Data of Parties; Party detail (Person detail, Gender, Source information), Organization, Address, Roles, Association, Biography, Synonymy ${ }^{29}$.

Narratives; Narrative detail, Summery, Description, Related, Hierarchy, Association

Multimedia; Resource information (title, creator), Description, Type (image, drawing, facsimiles).

Valuations; Valuation (object valued, valued by, value amount), Valuation type (reason for valuation, valuation notes). 
INTERNATIONAL JOURNAL OF

MULTIDISCIPLINARY STUDIES IN ARCHITECTURE

AND CULTURAL HERITAGE

there are categories about Conservations, Insurance, Rights ${ }^{30}$, Condition checks,Thesaurus, Groups as well ${ }^{31}$ (fig.4).

\section{Documentation impacts on collections management in the Egyptian museum}

Cairo: Documentation has acted important roles in collections management of Egyptian

Museum Cairo, since it was set registration and documentation systems in the second half of $19^{\text {th }}$ century to now. It served a museum, collections, and users. It helped a museum in acquisition, accession (permanent or temporary), deaccession (permanent or temporary),

\footnotetext{
${ }^{29}$ The Registration Collections Management and Documentation Department; Protocol Book. 44-6.

${ }^{30}$ Ibid. 47.

${ }^{31}$ Ibid. 43.
}

preservation and accountability, conservation and information on the history of object conservation, exhibitions (permanent or temporary), interpretation, and loan in \& out (resources for most regional museums and foreign exhibitions), resource of publication, method of educational programs, Archive to context and an access to data. In the recent yearsit has played an important role in repatriating hundreds objects stolen before, and during the $25^{\text {th }}$ January revolution actions. Moreover, digital documentation helped the curators in quickinventories and accounting total numbers of the recorded objects at the risk time. As digital documentation helps a museum to outreach new public in Egypt and all over world, in particular, the researchers, and who are interested in Egyptology to visit the 
INTERNATIONAL JOURNAL OF

MULTIDISCIPLINARY STUDIES IN ARCHITECTURE

AND CULTURAL HERITAGE

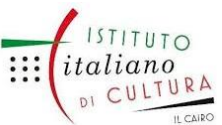

ISSN: $2735-4415$

VOLUME 2, ISSUE 2, 2019, 85 - 96.

www.egyptfuture.org/ojs/

Egyptian museumor to communicate with it by e-mail to request data or digital photos (fig. 5).

\section{Defects of documentation in the Egyptian museum:}

In spite the Egyptian museum Cairo has a long history of documentation works, but there are still a lot of defects like; there are no a filing system or organized archive (paper or photos archive), a documentation manual guiding curators on how to document in Arabic register books, updates to information of old catalogues, available web site, or publications on/off line. Many objects are still unaccountable or registered, especially existed in the basementstorage, because of the complex governmental procedures. Some register books are written inFrench, or English only and the others written in Arabic. Many objects don't have old photos or new photos, and they have lack of information, in particularly, acquisition data, techniquesdata, provenance.... Moreover, a new digital documentation system is written by English only.There is no an accurate accountability for the researchers, public or staff who are using differenttypes of documentation resources.

Finally, there are many administrative, organizational problems and conflicting duties among the different departments charged in documentation with less co-operation and co- ordination among them, besides, there are lack of documentation specialists, facilities and equipment. But in spite of these defects, the Egyptian museum Cairo is one of the best museums in Egypt on documentation, because it has various types of documentation (paper, digital, andmedia), and some staff well trained in Egypt and abroad. 
INTERNATIONAL JOURNAL OF

MULTIDISCIPLINARY STUDIES IN ARCHITECTURE

AND CULTURAL HERITAGE

ISSN: 2735-4415
VOLUME 2, ISSUE 2, 2019, 85 - 96.

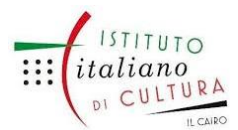

www.egyptfuture.org/ojs/

Received: February 15, 2018

Accepted: April 20, 2018 